\title{
CREATE THEIR OWN SPACE IN CYBERSPACE
}

\section{Anita FAMULA-JURCZAK - Mirostaw KOWALSKI}

\begin{abstract}
The purpose of the text is to show the importance of cyberspace in human development. The authors approached the concept of cyberspace. It shows areas of everyday life in which man can create your own space. The conclusions of an attempt to show the consequences that entails participation of individuals in cyberspace.
\end{abstract}

Key words: education, responsibility, cyberspace, information technology.

\section{KREOWANIE WLASNEJ PRZESTRZENI W CYBERPRZESTRZENI}

Streszczenie: $W$ tekście podjęta zostanie próba zaakcentowania znaczenia, które niesie za soba kreowanie przestrzeni $w$ cyberświecie. Autorzy ukazuja rozumienie pojęcia "przestrzeń" $i$ na tym tle buduja ramy niezbędne do analizowania podjętej problematyki. $W$ tekście zostaty ukazane równiez obszary, $w$ których jednostka może kreować własna przestrzeń. Autorzy na podstawie analizy literatury wskazuja na konsekwencje, jakie niesie za sobq udziat jednostki $w$ cyberprzestrzeni.

Slowa kluczowe: edukacja, odpowiedzialność, cyberprzestrzeń, technologie informacyjne.

\section{Create their own space in cyberspace}

In the literature of social sciences, issues considering broadly understood problems of the Internet are often taken. Issues relating Internet communication problems, his educational part, his part in creating, delivery and it usually is the accessibility of information is often propeled. With attention on ubiquity and the broad access, the Internet has been written on solid to our functioning (Naisbitt, 1984) and it contributed to rise of new society even how M. Castells (2008) affirms - the society of net.

The attempt to highlight the importance of which entails the creation of space in cyberworld will be undertaken in the text. With regard on ambiguity and dullness of the concept of space in the humanities will be made in his presentation in order to build the framework necessary to analysing the matter of subject undertaken. Then areas in which individual can create own space will be shown. And then the attempt to show the consequences that entails the participation of the individual in cyberspace will be shown in its conclusions.

\section{Cyberspace - the precision of time}

Can we talk about Internet users by creating a special space in which interactions occur? It is worth considering what is the space in general. The basic definitions of space can be found in the Dictionary of Polish Language (1999, p. 926), stating that it is "unlimited three-dimensional area in which there are all natural phenomena, some of that area covered by some sort of boundaries, too: the place occupied by an object, a vast, empty space without clearly marked, visible boundaries, the distance between something and something; general social phenomena, political, etc.". Analysis of the definitions contained in the Universal Encyclopedia indicates that the category of space is used in many fields of knowledge, among others. in mathematics, physics, geography. The work of the humanities and social sciences, we find the category of space. Interesting reflection on the spaces found in F. Znaniecki (quoted in: Nalaskowski, 2002) which has its division into: physical, geographical and social. Author argues that an individual experiences a variety of spaces that are qualitatively different, limited, not without tinges of emotional and evaluation. And, according to E. Hall (2003) space can be divided into stable, namely, that largely depends on age, and how the culture, because in these dimensions is constructed, its topography, the area is semi related to the activity of the individual. Slightly different understanding of space brings us a humanistic geographer - Yi-Fu Tuan. He argues that space is something neutral, and only giving it the importance of human causes that transforms into a place with the content of human existence (Yi-Fu Tuan, 1987). The issue was also taken 
space in pedagogy. A. Nalaskowski (2002) referring to the category of space makes the analysis of school buildings. Not consciously write about these issues more closely, they are merely an attempt to signal the presence of the category of space in various fields of knowledge. Interest to us we make a specific kind of space that is cyberspace.

What is a virtual space? According to Irene cyberspace can be defined as "a virtual space created by the accumulated resources of the Internet, or also as an illusion generated by special software and hardware" (Eren). It is also known as space relating to the virtual environment generated by a new generation of interactive computing community (Godzic, 1996). Interesting in the context of the functioning of cyberspace is considering $\mathrm{M}$. Graszewicza and D. Lewinski (2005). The authors evaluating several characteristics of cyberspace shows that there is difficulty in defining cyberspace.

You can also refer to the psychological features of cyberspace. K. Kaliszewska (2007, p. 17) in his work on the psychological determinants of cyberspace refers to studies Surtr, which presents the salient features of cyberspace. Its membership includes:

1. reducing sensory experience;

2. written text is the dominant form of contact;

3. appears here liquidity and anonymity in the contacts;

4. social barriers are removed, both cultural and social;

5. overcoming the blocks with distance;

6. temporary liquidity;

7. the versatility and diversity of social contacts;

8. to return to messages through their continuous record.

In the sense means that in cyberspace is limited possibility of physical contact and eye contact is limited and inextricably linked with the need to use online tools. Limited contact means selecting the information and the ability to create a new identity. Through the use of various forms of communication exist among the ability to create new friends.

It is a commonplace to say that over the evolution of society from industrial society to a society based on the information. J. Naisbitt in his book Megatredny indicates that "Computers are almost 54 percent. households. As a rule, they are holding, Shared, and consequently 62 percent. Poles have a computer at home. About 18 percent. from farms with a computer has more than one (which is just over 10 percent. of all farms). On equipped farms on one computer an average of 3.5 persons" (Batorski, 2006, p. 277). And, according to Manuel Castells 'networking' fosters new forms of communication, and as it goes becomes a source of a vast array of constructing virtual communities (Castells, 2008, p. 37). It is true that Mr Naisbitt in Megatrendach shows that networking is an essential element occurring in contemporary society. Additionally, the author points out that due to the availability of Internet resources and primarily through the development of all forms of communication to gain almost instantaneous flow of information . To present the characteristics of the individual in cyberspace include: "1 Interactive sending and receiving sygnałów1) 2 illusion involving the impression that it is actually $>$ team $<$. To this effect it is necessary to obtain the so-called. complete draft - at least two major senses, usually applies to sight and touch. The aim is to achieve economies of the so-called. virtual reality" (Bednarek, 2008, p. 278).

That is a reality that confusingly similar to the real world. Who uses this kind of reality?

According to the Ear "virtual society is an ideal place for people who for various reasons, can not find my place in the $>$ real $<$ world. (...) Where, however, runs so clear boundary between the virtual and the real world in everyday life? Both spaces seem to be subject to the same laws. Exclusion of one of them does not mean the immediate constitution of the other" (Kłos, 2009). However, according to Naisbitta our everyday world is saturated with virtuality. Posed, therefore, before the question about who benefits from the virtual world, as well as the quoted statement in the context of the ear may alternately described by J. and M. Castells Naisbitta seem unreasonable. It turns out that, in the virtual world is rooted majority of the population. You can therefore rely reformulate the question and seek answers to the question which elements of the social space described by F. Znaniecki even be found in the spaces created in cyberspace?

In short, you can point to some trends. First, the space of "virtual" is inherently inscribed in contemporary society. Secondly, the operation allows individuals to quickly make contacts, create their own identity, to build individual subjective perception of reality. 


\section{Cyberspace with the use}

The results of research carried out under the Social Diagnosis 2007 permit the conclusion that not only computers but also the Internet connection is present in almost everyday, every other Pole. The prepared report states that "The average number of hours spent on the Internet is 10.5. Up to 7 hours per week spent on the Internet 55 percent. users. Using up to two hours per week is around 24 percent. Persons exercising at least 21 hours per week are only 11 percent. users. The increase in time spent on Internet use is greater than the increase in time devoted to the use of computers. In March 2003, the average user spent on the web a little more than 6 hours per week in 2005, Internet users spend on average use of $81 / 2$ hours per week. While in 2007 it was already 10 and a half hours. This demonstrates a further increase in the role of the Internet in recent years. In 2003, the average Internet user spent on the network more or less 43 percent. time, which is devoted to the use of computers. In 2005 it was already 55 percent., And in March 2007 - 64 percent. It should be noted, however, that it is increasingly difficult to talk about time spent to use the Internet in a situation where the vast majority of computers are permanently connected to the Internet, and users are doing other things also use e-mail or IM. On the other hand, increase the time spent with the Internet is a reality and shows among other things, that more people now use the network at home, and much more is high speed. Greater availability of the Internet also favors strengthening the use of new users. In addition, together with the senior use of the Internet users begin a more comprehensive use of the network, and consequently spend more time on it. Increase the versatility of using the Internet, you can see by analyzing the actions that the Poles in the network perform. Of the 23 uses of the Internet, which we asked in both 2005 and in 2007, users now declare to perform an average of 11 of them. Two years ago, pledged an average of 9.5 steps. Increase the versatility of using the Internet is so clear" (Batorski, p. 277).

As shown by the data given by the authors of the Social diagnoses in recent years can be clearly seen an upward trend when it comes to using the Internet to create cyberspace. Accurate data presented in table

Table 1 Forms of Internet use (Source: Batorski)

\begin{tabular}{|c|c|c|c|c|}
\hline \multirow[t]{2}{*}{ How to use the Internet } & \multicolumn{2}{|c|}{$\begin{array}{l}\text { Acts performed within } 7 \\
\text { days before the test }\end{array}$} & \multicolumn{2}{|c|}{ The work ever } \\
\hline & 2005 & 2007 & 2005 & 2007 \\
\hline $\begin{array}{l}\text { Enabling instant messaging } \\
\text { conversations with friends (such as } \\
\text { ICQ, Gadu-Gadu, etc.) }\end{array}$ & 36 & 51 & 63 & 77 \\
\hline Participate in chat rooms & 13 & 14 & 55 & 54 \\
\hline $\begin{array}{c}\text { Participation in groups or } \\
\text { discussion forums }\end{array}$ & 8 & 15 & 36 & 46 \\
\hline $\begin{array}{c}\text { Create or modify their own } \\
\text { website or blog }\end{array}$ & 6 & 8 & 22 & 26 \\
\hline
\end{tabular}

Like the previously mentioned increase in the percentage of respondents who declare that they would ever use the Internet to contact others. Let us look at what is hidden under such terms as instant messaging, chat, forums - and the social networking site. It is true that the latter way of being in cyberspace has not been included in the study group presented by Mr Czapiński, it should be paid attention to him, because in recent years has become one of the most popular ways of "being" in the virtual world.

As I review the dictionary has been made today's most popular IM networks. There we read that the communicator (called Instant Messenger
- instant communication) is "a program that allows for direct communication via the Internet or local network using text messaging, voice and multimedia communications. That two Internet users can communicate with each other, both must have identical or compatible with each other communicators. Direct communication is conducted in real time (compared to e-mail) (www.i-slownik.pl/ of 14.12. 2009).

According to a study presented above, the way of "being" on the Internet is also the use of chat rooms. It is a form of communication similar to that discussed above. Consists of a conversation in real time with others who are in 
the Internet. Communication takes place usually by typing text messages that are displayed on the screens of other participants. (...) Most of these sites focuses on a particular topic, allowing them to interested parties exchange experiences and information. It happens that the talks are invited famous people or experts in the field - then the course of this meeting is usually stored and made available as an archive. Not missing the typical entertainment "party-lines" as well as places for the players - the so-called. chat worlds. (www.islownik.pl/ of 14.12. 2009).

To build the identity of the network are used primarily so. Private space in cyberspace: blogs and private homepages. In this form one does not impose a user topic expression.

M.M Pegowski (2008, p. 47-53) referring to the large literature indicates that Webblog, which is commonly known is a blog, although initially served a personal purpose, its role today has evolved. The current virtual reality, we find not only various types of blogs (from webblogów by photo-and v-blogs blogs until the multi-purpose.

Another form of virtual space is to build community portals that are characterized by the ability to create their own profile that contains the selected personal data. Their content is selected by the user. They also allow to search for friends, creating a list of contacts and communication. Participation in these portals can be individualistic and social dimension. The first one, allows for self-presentation and choice of friends. Second, it allows to establish and consolidate social ties connecting the unit with others. Participants experience the social networking site, not only individualism, but considered themselves the most important relationships, they are perceived as a autotelic, but may also serve as a means to achieve another purpose, for example: search for new contacts, mutual assistance in carrying out tasks or exchange of goods or services. The purpose of a network of mutual support and strengthen rather than rivalry or climb over the other.

\section{Why do young people seek to create a cyberspace?}

R. Havighurst notes that the important developmental tasks that have to meet a young man should be interpersonal contacts and hence the search for answers to the question about who I am, and on this background, shaping its identity. It should be emphasized that it is built by reference to the significant other and build on the accepted definition of the image itself. This can be done in the real world, but more often it takes place in cyberspace. H. Wawrzynowicz writes "Creating a network of personality is an important process that gave rise to produce a particular impression on the people with whom we contact through the Internet. Since the elemental tool of Internet communications is the word, then by what we write for example in e-mail, messages sent to other users, we are creating the image of our party. Our caller, or partners, Pen did not know us personally, in the real world, do not have a comparative context. Their only knowledge of our identity comes from the interaction network. The image we are creating a communication on the basis of communications we receive, and in this case is easily susceptible to misinterpretation of the message appears on the screen and create a false image of the other person" (www.21.edu.pl/ks/3/317.doc. of 14.12.2009).

Although the functioning of individuals in cyberspace is an essential component of information-based society, it seems necessary to draw attention to the negative consequences as a result of too intensive use of virtual reality. K. Kaliszewska referring to research conducted by the team, led by Kraut, indicates that excessive involvement of the users in virtual reality can lead to a reduction of involvement in the actual interpersonal relations. An indispensable corollary of this situation is a growing sense of loneliness, social isolation and depressed mood and decrease life satisfaction. However, there is another face of human functioning in virtual reality. Its creation and participation in virtually created the world, among people I know but it really is for us anonymous interlocutors, allows for social support.

J. Gajda (2005, p. 146), as indicated by the danger that entails creating your own space in the virtual world is blurring of identities. Author points out that the interent 'abolishing restrictions-space, creates a tremendous opportunity to conceal a genuine identity, manipulation, and its various forms of selfcreating. Using the metaphor of the theater proposed by E. Goffman (2000) can say that cyberspace users can play different roles, as "visual confrontation so far is unavailable".

Pointed out above means "being of the individual in cyberspace". Pointed out the widespread use of various forms of that presence. showed the risks that entails the creation of their own identity in cyber-world. At this point, we consider whether it is possible to dispense with 
this form of "being in the world"? Recall that this places the words of M. Castells, who believes that is inevitable in the functioning of the network society, the absence of it makes it not exist.

\section{Literature:}

[1] BATORSKI, D., Uwarunkowania i konsekwencje korzystania $z$ technologii informacyjno -komunikacyjnych, [w:] J. Czapiński, T. Panek (red.), Diagnoza Społeczna 2007: Warunki i jakość życia Polaków, Wydawnictwo Vizja Press\&IT, Warszawa.

Bednarek J., Media w nauczaniu, Wydawnictwo MIKOM, Warszawa 2006.

[2] CASTELLS, M., Spoleczeństwo sieci, Państwowe Wydawnictwo Naukowe, Warszawa 2008.

Eren, Zagubieni w cyberprzestrzeni, WWW.cyberkultura.pl/contetnt, php?condit $=3 . \mathrm{z}$ dnia 14.12.2009

[3] GAJDA, J., Media w edukacji, Oficyna Wydawnicza „Impuls”, Kraków 2005.

[4] GODZIC, W., Ogladanie i inne przyjemności kultury popularnej, Kraków 1996.

[5] GOFFMAN, E., Czlowiek $w$ teatrze życia codziennego, Wydawnictwo KR, Warszawa 2000.

[6] GRASZEWSKI， M., LEWIŃSKI， D., $O$ nieistnieniu cyberprzestrzeni, [w:]

Język@multimedia, A. Dyman-Stasieńko, J. Stasieńko (red.), Wydawnictwo Naukowe DSWE TWP, Wrocław 2005.

[7] HALL, E., Ukryty wymiar, Wydawnictwo MUZA, Warszawa 2003.

http://www.i-slownik.pl/ z dn. 14.12. 2009.

[8] KALISZEWSKA, K., Nadmierne używanie Internetu. Charakterystyka psychologiczna, Wydawnictwo Naukowe UAM, Poznań 2007.

Kłos A., Blogi, nekrologi. Szaleństwo w sieci, Witryna, $\quad \mathrm{nr} \quad 2$ http://witryna.czasopism.pl/pl.gazeta, $\quad \mathrm{z}$ dnia 14.12.2009.
[9] NAISBITT, J., Megatrendy, Wydawnictwo Zysk i Sk-a, Poznań 1984.

[10] NALASKOWSKI, A., Przestrzenie i miejsca szkoty, Oficyna Wydawnicza „Impuls”, Kraków 2002.

[11] PEOWSKI, M.M., Blog tematyczny jako narzędzie edukacyjne - perspektywy, szanse, zagrożenia, [w:] Spoleczne konteksty Internetu. Implikacje dla edukacji, Wydawnictwo Gdańskiej Wyższej Szkoły Humanistycznej, D. Muszyńska, G.D. Stunaż (red.), Gdańsk 2008.

Stownik Języka Polskiego, Państwowe Wydawnictwo Naukowe, Warszawa 1999.

Tuan Yi-Fu, Przestrzeń $i$ miejsce, PIW, Warszawa 1987.

[12] WAWRZYNOWICZ, H., Obywatele siecitworzenie sie spoleczności, www.21.edu.pl/ks/3/317.doc. z dnia 14.12.2009.

[13] ZNANIECKI, F., Socjologiczne podstawy ekologii ludzkiej, [w:] „Ruch Prawniczy, Ekonomiczny i Socjologiczny”, Poznań 1938.

\section{Prof. Mirosław Kowalski \\ Dr Anita Famuła-Jurczak \\ Uniwersytet Zielonogórski \\ Al. Wojska Polskiego 69 \\ 65-001 Zielona Góra \\ Tel: +48 517608846 \\ E-mail: M.Kowalski@ipp.uz.zgora.pl \\ afamu@o2.pl}

